\title{
Influence of hydraulic retention time and amplitude of water level fluctuations on water quality in irrigation reservoirs of the Kala Oya river basin, Sri Lanka
}

Sareeha Nadarajah $^{1 \dagger}$, W.M.H. Kelum Wijenayake ${ }^{2}$, Nuwan D.P. Gunawardane ${ }^{3}$ and Upali S. Amarasinghe ${ }^{1 *}$

${ }^{1}$ Department of Zoology and Environmental Management, University of Kelaniya, Kelaniya, Sri Lanka

${ }^{2}$ Department of Aquaculture and Fisheries, Faculty of Livestock Fisheries and Nutrition, Wayamba University of Sri Lanka, Makandura, Gonawila (NWP), Sri Lanka

${ }^{3}$ Department of Fisheries and Aquatic Resources, New Secretariat, Maligawatte, Colombo 10, Sri Lanka

${ }^{\dagger}$ Present address: Sri Lanka German Training Institute, Ariviyal Nagar, Kilinochchi, Sri Lanka

* Correspondence (zoousa@kln.ac.lk)

http://orcid.org/0000-0002-0465-6950

\begin{abstract}
Management of reservoir water quality is a global challenge due to the natural process of eutrophication and anthropogenic aggravation. In Sri Lanka, irrigation reservoirs support several secondary uses such as fish production, livestock farming, and many communal uses including drinking water supply. In the present study, basic limnological parameters of ten irrigation reservoirs of Sri Lanka were investigated from June 2013 to February 2016, with a view to identifying influence of hydrological regimes on reservoir water quality. Spatio-temporal similarities of water quality parameters were studied employing the self-organizing map (SOM) routine of the artificial neural network application. The sample vectors, classified on the SOM lattice, indicated 6 clusters at 50\% similarity level. When reservoir that were categorized according to hydraulic retention time (HRT) and relative reservoir level fluctuation (RRWL; defined as the ratio of the mean reservoir level amplitude to mean depth), were compared with dominant water quality parameters in SOM lattice, it was evident that some productivity-related water quality parameters were influenced HRT and RRWL. The results of the study revealed that HRT and RRWL can essentially be controlled through management of hydrological regimes in irrigation reservoirs, thus, close dialogue between irrigation authorities and other users of reservoir water resources are needed to ensure desired water quality of the reservoirs.
\end{abstract}

Keywords: artificial neural network, nutrient loading, reservoir limnology, self-organizing maps, tropical reservoirs

\section{INTRODUCTION}

Sri Lanka is endowed with rich reservoir resources and the cumulative extent of reservoirs is about 206,000 ha (Jayasinghe and Amarasinghe 2018). This is perhaps the highest density of reservoirs in the world, which is worked out to be about 3.1 ha of reservoir area per every $\mathrm{km}^{2}$ of the island (Fernando 1993). The total extent of reservoirs in the country consists of ancient reservoirs constructed irrigating agricultural lands and, recently constructed upland reservoirs are used for hydroelectricity generation several other purposes. Apart from these primary uses, reservoir resources support several secondary uses such as fish production, livestock farming, and communal uses such as bathing, drinking water supply etc. Eutrophication in aquatic ecosystems is one of the major widespread problems worldwide. This natural process is often aggravated due to anthropogenic activities due to accelerated runoff of materials from the land surface to water bodies (Rast and Holland 1988). Therefore, monitoring and managing lakes and reservoirs would be important to have desired water quality in lakes and reservoirs and also to prevent or limit eutrophication (Wagner and Erickson 2017).

Reservoirs with longer a hydraulic retention time (HRT) may exhibit conditions prevailing in natural lakes and are generally characterized by prolonged nutrient retention (Kennedy 2005). In irrigation 


\section{S. Nadarajah et al.}

reservoirs, due to regular water releases to the agricultural lands, HRT is expected to be lower than in other lentic water bodies where outflowing water is minimal (Kawara et al. 1998). Further, the magnitude of reservoir drawdown had a significant positive influence on fish yield in a Sri Lankan reservoir (De Silva 1985). Kolding and van Zwieten (2006, 2102) have also shown that amplitudes of reservoir level had positive influences on fish yield. Similar positive influences of reservoir level amplitude on fish yields in Sri Lankan reservoirs were reported by Amarasinghe and De Silva (2015).

HRT and fluctuations in the reservoir water level are essential hydrological features, which are mainly related to water releases from reservoirs. Thus, understanding of their influences on reservoir water quality would provide important management implications. In the present paper, an attempt was made to investigate, employing a multivariate statistical approach, the spatio-temporal patterns of water quality in ten irrigation reservoirs of Sri

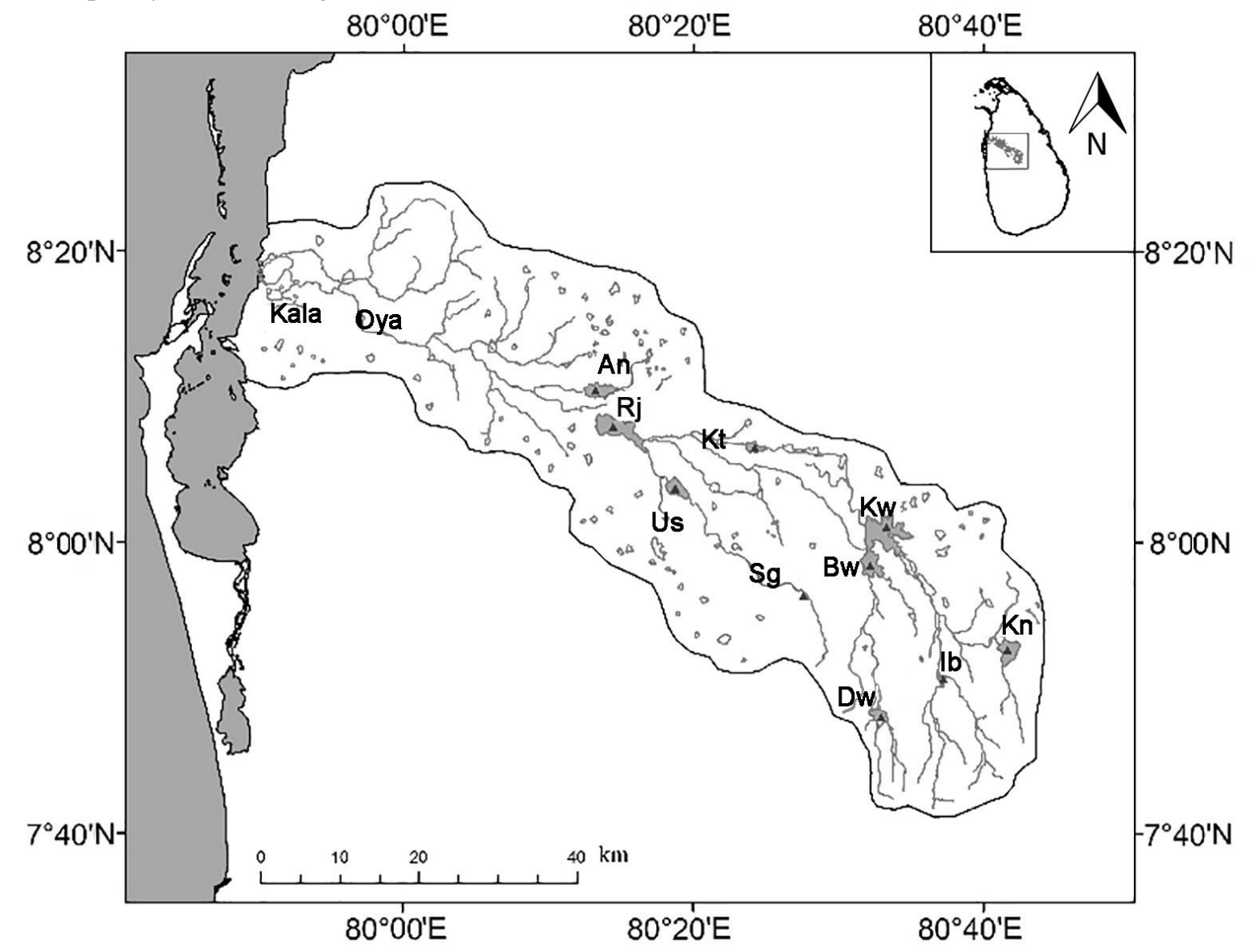

Fig. 1 Map of the study area with reservoirs of Kala Oya river basin. Reservoirs; An - Angamuwa; Bw Balaluwewa; Dw - Dewahuwa; Ib - Ibbankatuwa; Kw - Kalawewa; Kn - Kandalama; Kt - Katiyawa; Rj Rajanganaya, Sg - Siyambalangamuwa; Us - Usgala Siyambalangamuwa.
Lanka in relation to hydraulic retention time and amplitude of water level fluctuations. This study is therefore aimed at understanding importance managing hydrological regimes in the water quality management of irrigation reservoirs.

\section{MATERIALS AND METHODS}

\section{Data collection}

Ten irrigation reservoirs of Kala Oya river basin in Sri Lanka were selected for the present study. Geographic locations of the reservoirs are shown in Figure 1 and some morphometric characteristics of these reservoirs are given in Table 1. Hydrological data including reservoir volume and annual outflow volume of the reservoirs were obtained from the Irrigation Department and Mahaweli Authority of Sri Lanka. 
Table 1 Morphometric characteristics of ten irrigation reservoirs selected for the present study. (Sources: Irrigation Department; Mahaweli Authority of Sri Lanka). Abb. - Abbreviation of reservoir name. FSL full supply level; MSL - mean sea level; MCM - million cubic metres

\begin{tabular}{llrrrr}
\hline Reservoir & Abb. & $\begin{array}{r}\text { The } \\
\text { extent at } \\
\text { FSL (ha) }\end{array}$ & $\begin{array}{r}\text { Capacity at } \\
\text { FSL (MCM) }\end{array}$ & $\begin{array}{r}\text { FSL (m } \\
\text { above MSL) }\end{array}$ & $\begin{array}{r}\text { Catchment } \\
\text { area }\left(\mathrm{km}^{2}\right)\end{array}$ \\
\hline Angamuwa & $\mathrm{An}$ & 792 & 15.79 & 64.3 & 129.5 \\
Balaluwewa & $\mathrm{Bw}$ & 934 & 41.42 & 120.0 & 269.8 \\
Dewahuwa & $\mathrm{Dw}$ & 433 & 13.56 & 182.9 & 67.3 \\
Ibbankatuwa & $\mathrm{Ib}$ & 405 & 11.72 & 162.2 & 169.0 \\
Kalawewa & $\mathrm{Kw}$ & 1980 & 87.81 & 129.2 & 572.0 \\
Kandalama & $\mathrm{Kn}$ & 736 & 33.74 & 176.2 & 98.0 \\
Katiyawa & $\mathrm{Kt}$ & 257 & 5.55 & 94.3 & 86.7 \\
Rajanganaya & $\mathrm{Rj}$ & 1599 & 100.37 & 68.3 & 1611.0 \\
Siyambalangamuwa & $\mathrm{Sg}$ & 146 & 2.6 & 36.3 & 46.6 \\
Usgala Siyambalangamuwa & $\mathrm{Us}$ & 769 & 26.72 & 86.8 & 184.6 \\
\hline
\end{tabular}

Each reservoir was visited approximately once in two months from June 2013 to February 2016 and three predetermined sampling sites were used to collect water samples to determine physicochemical and biological parameters. All the samples were taken at the 0.5 metre depth from the surface. Water temperature, $\mathrm{pH}$, conductivity, dissolved oxygen, total alkalinity and, Secchi depth, were measured at the site itself. Water samples were kept in ice box during transportation and total phosphorus and nitrate were analysed using the standard spectrophotometric methods (Table 2). For determination of chlorophyll-a and seston weight, water samples were filtered in situ using nitrocellulose membrane filters (pore size - $0.45 \mu \mathrm{m}$; diameter $-47 \mathrm{~mm}$ ) by a hand-held filter set-up and the filter papers were wrapped with aluminium foil, kept in an ice box until bringing to the laboratory for further analysis. The methods of determination of physico-chemical and biological parameters in the present study are given in Table 2 .

Table 2 The water quality parameters investigated and the procedures employed.

\begin{tabular}{|c|c|c|}
\hline Parameter & Abbreviation & Procedure \\
\hline Alkalinity & Alk & $\begin{array}{l}\text { Standard titrimetric method, Mixed bromcresol green- } \\
\text { methyl red indicator solution, } 0.1 \mathrm{~N} \text { standard } \mathrm{HCl} \\
\text { (APHA 2012) }\end{array}$ \\
\hline Chlorophyll- $a$ & Chl-a & $\begin{array}{l}\text { Spectrophotometric method with acetone extraction } \\
\text { (Carlson \& Simpson 1996; APHA 2012) }\end{array}$ \\
\hline Electrical conductivity & $\mathrm{EC}$ & Electric conductivity meter (Hanna; HI86303) \\
\hline Dissolved oxygen & DO & Winkler method (APHA 2012) \\
\hline Nitrate & $\mathrm{NO}_{3}^{-}$ & Cadmium reduction method (APHA 2012) \\
\hline $\mathrm{pH}$ & $\mathrm{pH}$ & Membrane $\mathrm{pH}$ meter (Cyberscane; pH300) \\
\hline Secchi disc depth & SDD & $\begin{array}{l}\text { 20-cm diameter, alternate black-and-white segment } \\
\text { Secchi disc }\end{array}$ \\
\hline Water temperature & Temp & Mercury thermometer \\
\hline Total Phosphorus & $\mathrm{TP}$ & $\begin{array}{l}\text { Ascorbic acid method, following persulphate digestion } \\
\text { (APHA 2012) }\end{array}$ \\
\hline Seston weight & SW & $\begin{array}{l}\text { Drying filtered particles on nitro-cellulose filter at } 80^{\circ} \mathrm{C} \\
\text { in oven with fan (Wetzel 2001) }\end{array}$ \\
\hline
\end{tabular}




\section{Data analysis}

Underpinning patterns similarity and dissimilarity of water quality parameters in 10 reservoirs were investigated using the self-organizing map (SOM) routine of Artificial Neural Network (ANN) application (Kohonen 2001). This unsupervised algorithm of ANN application is an artificial intelligence approach for analyzing, clustering and modeling of multiple variables, and is thought to be appropriate for the present study because it allows analysis of complex data sets (Lek et al. 2005; Suryanarayana et al. 2008). The output of SOM is displayed as a hexagonal lattice and classifies the sample vectors (SVs), described by a set of descriptors on the map according to the similarities between the descriptors (i.e., water quality parameters). During the learning process, two SVs with similar descriptors are classified in the same or neighboring cells, whereas two different SVs are classified in separated cells that could be distant from each other. The number of map units $(\mathrm{C})$ or neurons for the output layer (i.e., map size) was determined as $C=5^{*} \sqrt{ }$, where $n$ is the number of samples (SVs), as proposed by the Laboratory of Computer and Information Science, Helsinki University of Technology (Kohonen, 1982; Tudesque et al., 2008). As the number of samples in the present study was 164 , estimated $\mathrm{C}$ was 64 , and consequently the map size of $8 \times 8$ output neurons was defined. The hierarchical cluster analysis (Euclidean distance), as articulated in ANN software, was also employed to illustrate the levels of similarity between clusters. The Artificial Neural Network Toolbox V.4 operating in Matlab environment was used for developing ANN and SOM (Vesanto 2000; Yu et al. 2011).

To investigate spatial patterns of reservoir water quality, percentage samples corresponding to each reservoir was determined in each cluster resulted from SOM analysis. The dominance of each reservoir in the SOM clusters was then compared with the dominant water quality parameters in different SOM clusters that are illustrated in the component plan of each water quality parameter in the SOM.

Hydraulic retention time (HRT in yrs) of each reservoir was determined by the following equation (Dillon 1975).

$$
\mathrm{HRT}=\frac{\text { Reservoir volume in MCM }}{\text { Annual outflow (MCM/yr) }}
$$

Reservoirs that were grouped into four categories based on the values of HRT as $<25 \%, 25 \%-50 \%$, $50 \%-75 \%$ and, $>75 \%$. Mean annual relative reservoir level fluctuation (RRLF) in each reservoir was calculated as follows (Kolding and van Zwieten 2006):

$$
\mathrm{RRLF}=\frac{\mathrm{WL}_{\text {Max }}-\mathrm{WL}_{\text {Min }}}{\text { Mean Depth }} \times 100
$$

where, $\mathrm{WL}_{\mathrm{Max}}=$ Maximum water level in $\mathrm{m}, \mathrm{WL}_{\mathrm{Min}}$ $=$ Minimum water level in $\mathrm{m}$, and mean depth is in $\mathrm{m}$. Based on the values of RRLF, reservoirs were again grouped into three categories as RRLF $<100$; $100-200$ and $>200$.

The dominant water quality parameters in reservoirs, that could be determined from the component plan of each water quality parameter in the SOM, in relation to categories of HRT and RRWL, were then determined. To substantiate the findings of these analyses, dominant water quality parameters were related to HRT and RRWL.

\section{RESULTS}

Water quality parameters measured in the 10 reservoirs showed appreciable variations between reservoirs (Fig. 2). Of these water quality parameters, chlorophyll-a content showed the greatest variation. In Ibbankaruwa reservoir, where hydraulic retention time is the lowest (Fig. 3), the highest nitrate concentration $\left(5.48 \mathrm{mg} \mathrm{l}^{-1}\right)$, lowest $\mathrm{pH}$ (7.68), lowest Secchi depth (0.69 m), and lowest water temperature $\left(27.0^{\circ} \mathrm{C}\right)$, were recorded (Fig. 2). 

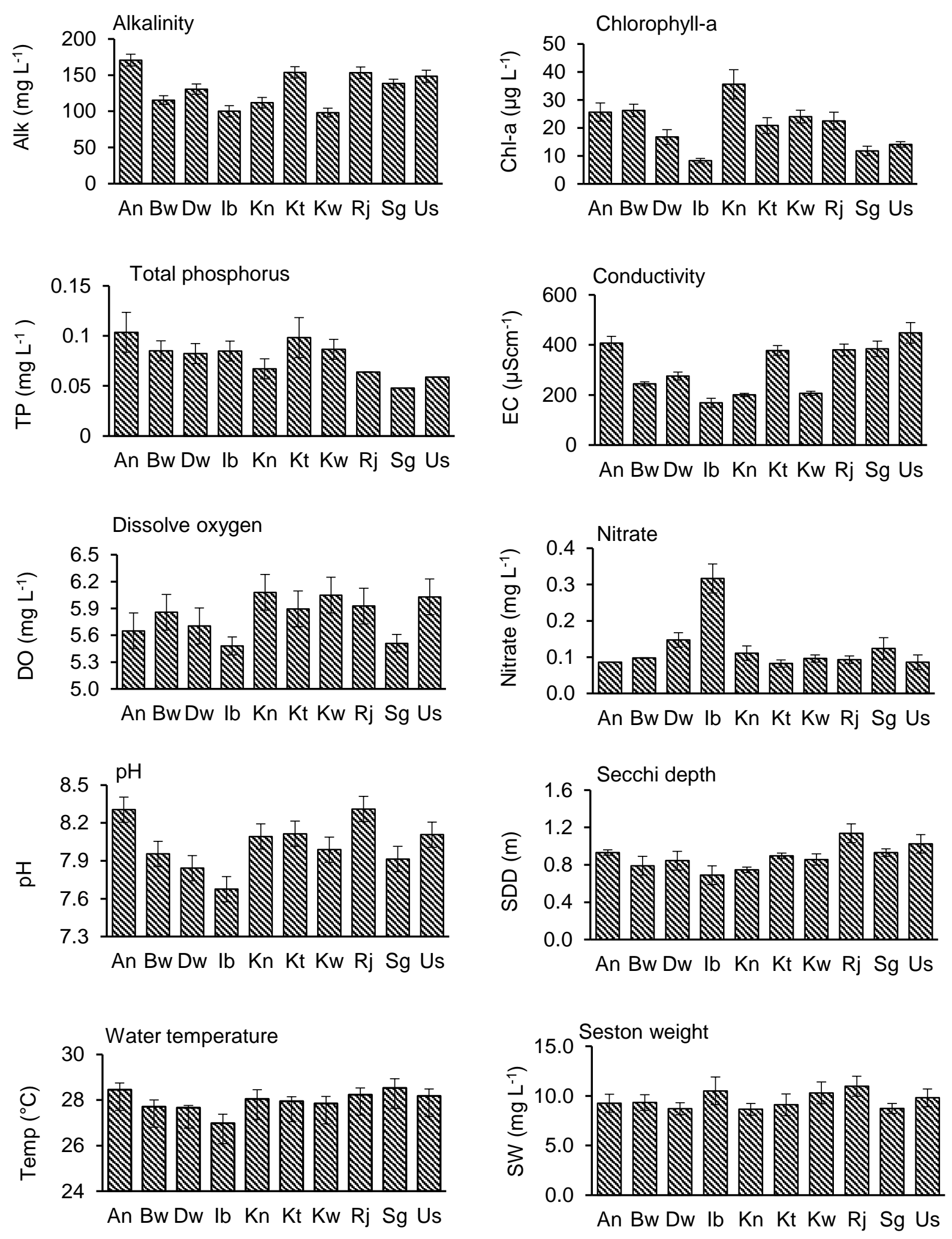

Fig. 2 Water quality parameters (mean \pm SE) in 10 irrigation reservoirs. Abbreviations of reservoir names are as given in Table 1. Abbreviations of water quality parameters are as given in Table 2. 
The Hydraulic Retention Time (HRT) of the 10 reservoirs studied, varied greatly between each reservoir (Fig. 3A). According to the results of the HRT, Angamuwa, Balaluwewa, Ibbankatuwa, Kandalama and Katiyawa belong to the category of HRT of $<0.5$ yrs, Rajanganaya and Siyambalangamuwa to the category of HRT of 0.5$1.0 \mathrm{yrs}$, Usgala Siyambalangamuwa to the HRT of 1.0-1.5 yrs and Dewahuwa to the category of the

(A)

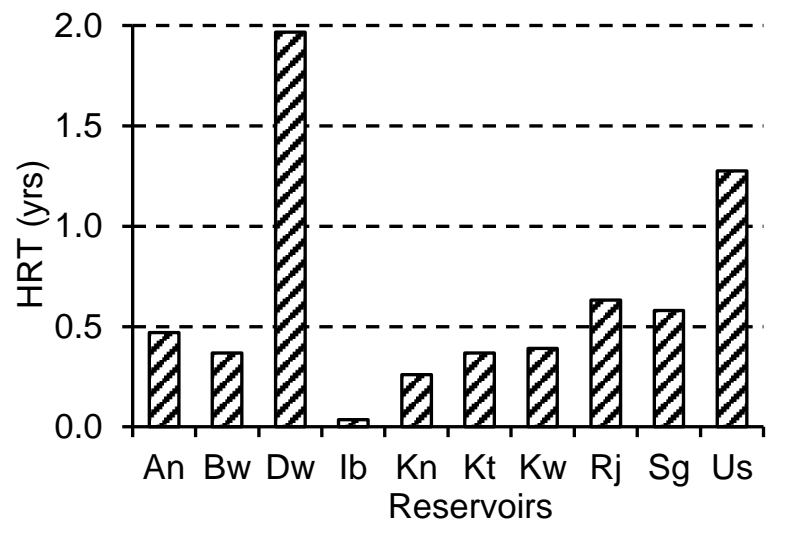

highest HRT (>1.5 yrs). Based on Relative Reservoir Water Level fluctuations (RRWL), Kandalama and Rajanganaya registered low $(<100)$ RRWL, Angamuwa, Balaluwewa, Katiyawa, Kalawewa and Usgala Siyambalangamuwa were characterized as intermediate (100-200) RRWL, and Dewahuwa, Ibbankatuwa and Siyambalangamuwa high (>200) RRWL (Fig. 3B).

(B)

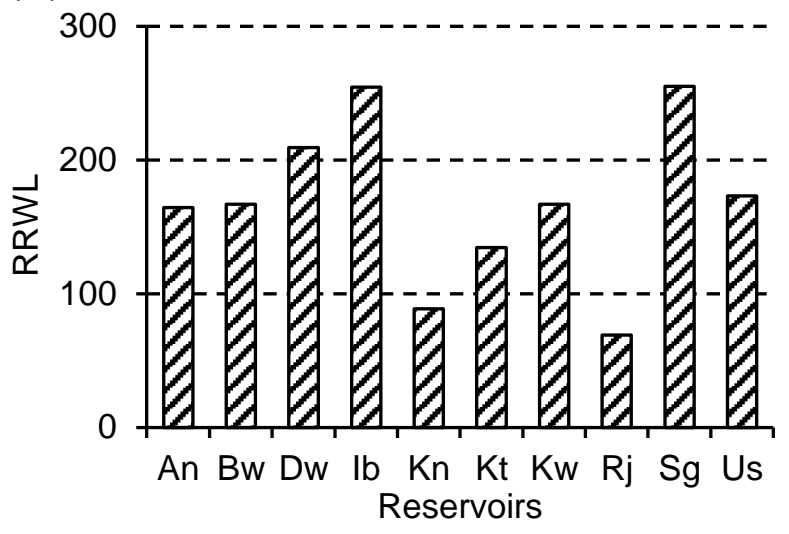

Fig. 3 Hydraulic retention time (HRT) and Relative Reservoir Water Level fluctuations (RRWL) in the 10 reservoirs studied. (A) Horizontal broken lines indicate arbitrary categorization of reservoirs based on HRT $(<0.5 \mathrm{yrs}, 0.5-1.0 \mathrm{yrs}, 1.0-1.5 \mathrm{yrs}$, and $>1.5 \mathrm{yrs})$ and (B) horizontal broken lines are the arbitrary categorization of reservoirs based on RRWL $(<100,100-200$, and $>200)$. Abbreviations of reservoir names are as given in Table 1.

The sample vectors (observations) in the present study, classified on the SOM lattice (Figure 4A) indicate that there were 6 clusters and in the similarity dendrogram (Figure 4B), these six clusters could be found at about $50 \%$ similarity level. Based on the samples that were represented by each cluster (Table 2), percentage samples of the 10 reservoirs in the six clusters were determined (Figure 5). From these plots, it is evident that Dewahuwa and Siyambalangamuwa had higher proportions of samples in cluster I, Balaluwewa in clusters II and V, Usgala Siyambalangamuwa and Rajanganaya in cluster III, Angamuwa and
Katiyawa in cluster IV, Kandalama and Kalawewa in cluster $\mathrm{V}$, and Ibbankatuwa in cluster VI.

When the component plans of water quality parameters on the SOM lattice (Figure 6) are compared with the proportions of samples of reservoirs in the six clusters, spatial variations of water quality parameters could be identified.

The reservoirs, grouped according to HRT and RRWL (Figure 3), and characterized by dominant water quality parameters were then identified from the component plans of SOM lattice (Figure 6). The results are summarized in Table 4. 
(A)

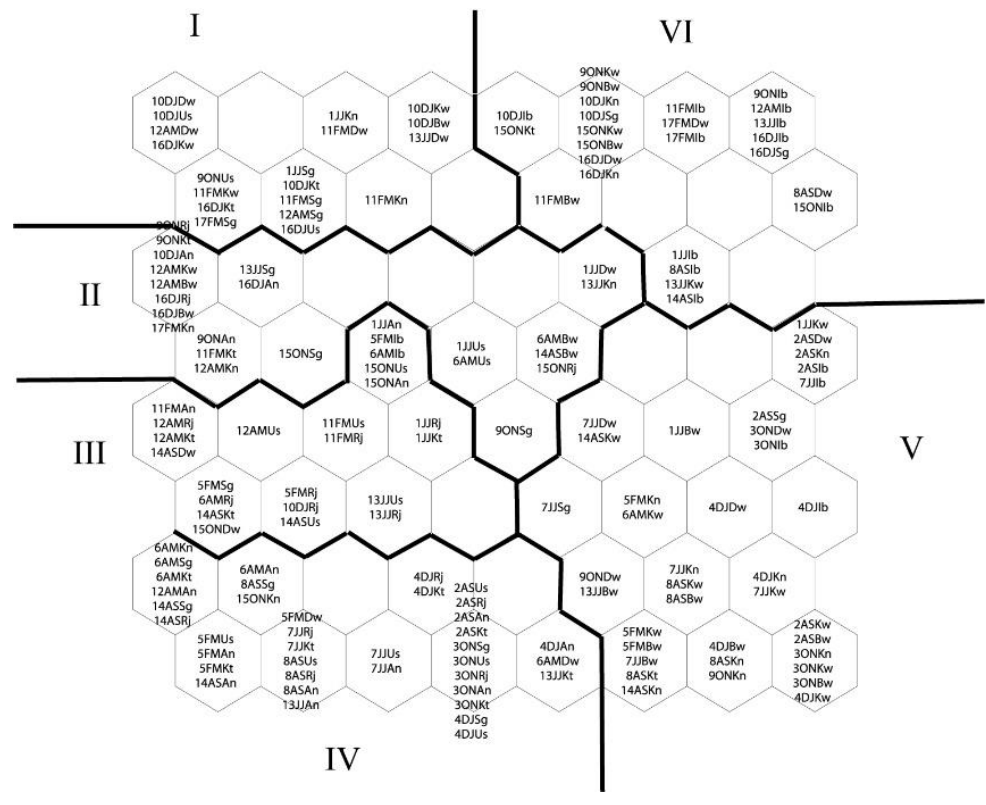

(B)

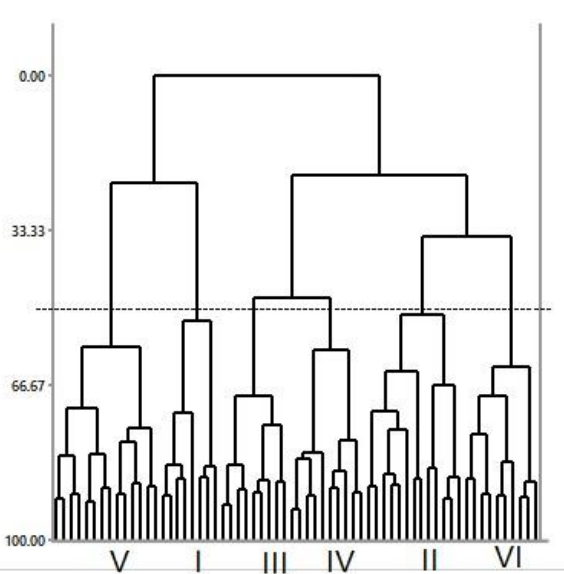

Fig. 4 Results of the SOM analysis. (A) Classification of sample vectors based on water quality parameters; and (B) Dendrogram of the SOM output, showing six clusters of sample vectors with similar water quality parameters. Definition of symbols is given in the caption of Table 3.

Table 3 The number of samples in the six clusters of SOM analysis. Sample codes represent sampling visit month and reservoir name (e.g., 10DJDw represents 10 sampling visit in December-January to Dewahuwa). Abbreviations of reservoir names are as given in Table 1.

\begin{tabular}{|c|c|}
\hline Cluster & Samples \\
\hline I & $\begin{array}{l}\text { 10DJDw, 12AMDw, 11FMDw, 13JJDw, 10DJUs, 16DJUs, 16DJKw, 11FMKw, 10DJKw, } \\
\text { 16DJKt, 10DJKt, 17FMSg, 11FMSg, 1JJSg, 12AMSG, 1JJKN,11FMKN, 10DJBw, } \\
\text { 9ONUs }\end{array}$ \\
\hline II & $\begin{array}{l}\text { 10DJAn, 9ONAn, 16DJAn, 12AMBw, 16DJBw,14AsBw,6AMBw,12AMKw, 16DJRj, } \\
\text { 9ONRj, 15ONRj, 17FMKn, 12AMKn, 13JJKn, 9ONKt, 11FMKt, 13JJSg,15ONSg, } \\
\text { 9ONSg, 1JJUs, 6AMUs }\end{array}$ \\
\hline III & $\begin{array}{l}\text { 11FMAn, 15ONAn, 1JJAn, 12AMKt, 14ASKt,1JJKt, 12AMRj,6AMRj, 10DJRj, 5FMRj, } \\
\text { 11FMRj,13JJRj, 1JJRj, 14ASDw, 15ONDw, 5FMSg, 12AMUs, 14ASUs, 15ONUs, } \\
\text { 11FMUs, 13JJUs, 5FMIb, 6AMIb }\end{array}$ \\
\hline IV & $\begin{array}{l}\text { 12AMAn, 14AsAn, 5FMAn, 6AMAn, 13JJAn, 8ASAn,7JJAn,2ASAn, 3ONAn, 4DJAn, } \\
\text { 14ASRj, 7JJRj, 8ASRj, 4DJRj, 2ASRj,3ONRj, 14ASSg, 6AMSg, 8ASSg, 3ONSg, 4DJSg, } \\
\text { 6AMKn, 15ONKn,6AMKt, 5FMKt, 7JJKt, 4DJKt, 2ASKt, 3ONKt, 13JJKt, 5FMUs, } \\
\text { 8ASUs, 7JJUs, 2ASUs, 3ONUs,4DJUs, 5FMDw, 6AMDw }\end{array}$ \\
\hline V & $\begin{array}{l}\text { 7JJSg, 2ASSg, 14KSKw, 6AMKw, 5FMKw, 8ASKw, 1JJKw, 7JJKw, 2ASKw, 3ONKw, } \\
\text { 4DJKw, 7JJDw, 9ONDw, 4DJDw, 2ASDw, 3ONDw, 5FMKn, 14ASKn, } \\
\text { 7JJKn,8ASKn,3ONKn, 9ONKn, 2ASKn, 4DJKn,13JJBw, 5FMBw, 7JJBw, 1JJBw, } \\
\text { 8ASBw, 4DJBw, 2ASBw, 3ONBw, 8ASKt, 2ASIb, 7JJIb, 3ONIb, 4DJIb }\end{array}$ \\
\hline VI & $\begin{array}{l}\text { 12AMIb, 13JJIb, 16DJIb, 9OnIb, 10DJIb, 11FMIb, 17FMIb, 15ONIb, 14ASIb, 1JJIb, } \\
\text { 8ASIb,15ONKt, 11FMBw, 15ONBw, 9ONBw, 10DJKn, 16DJKn, 10DJSg, 16DJSg, } \\
\text { 15ONKw, 9ONKw, 13JJKw, 16DJDw, 17FMDw, 8ASDw }\end{array}$ \\
\hline
\end{tabular}



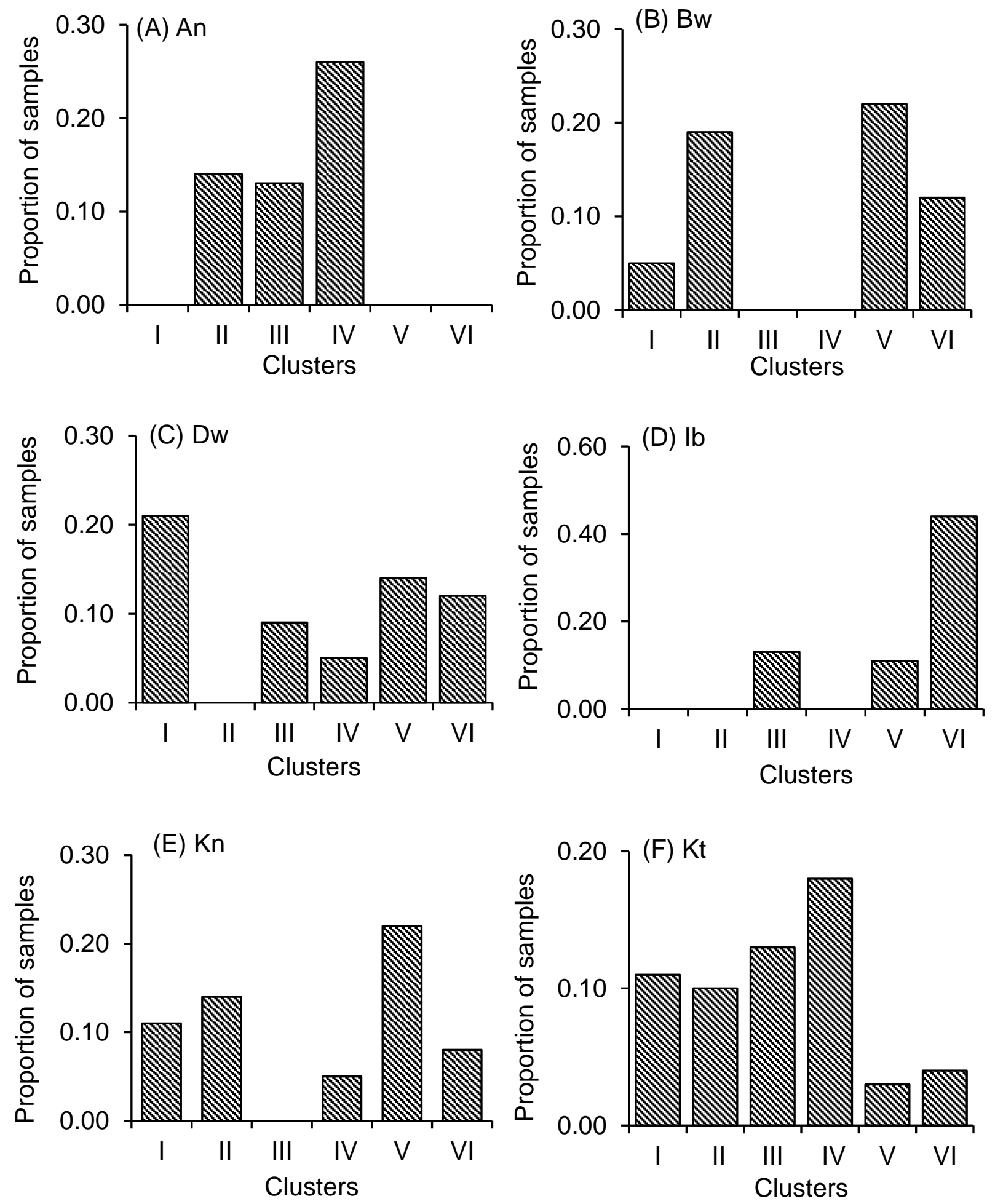
S. Nadarajah et al.
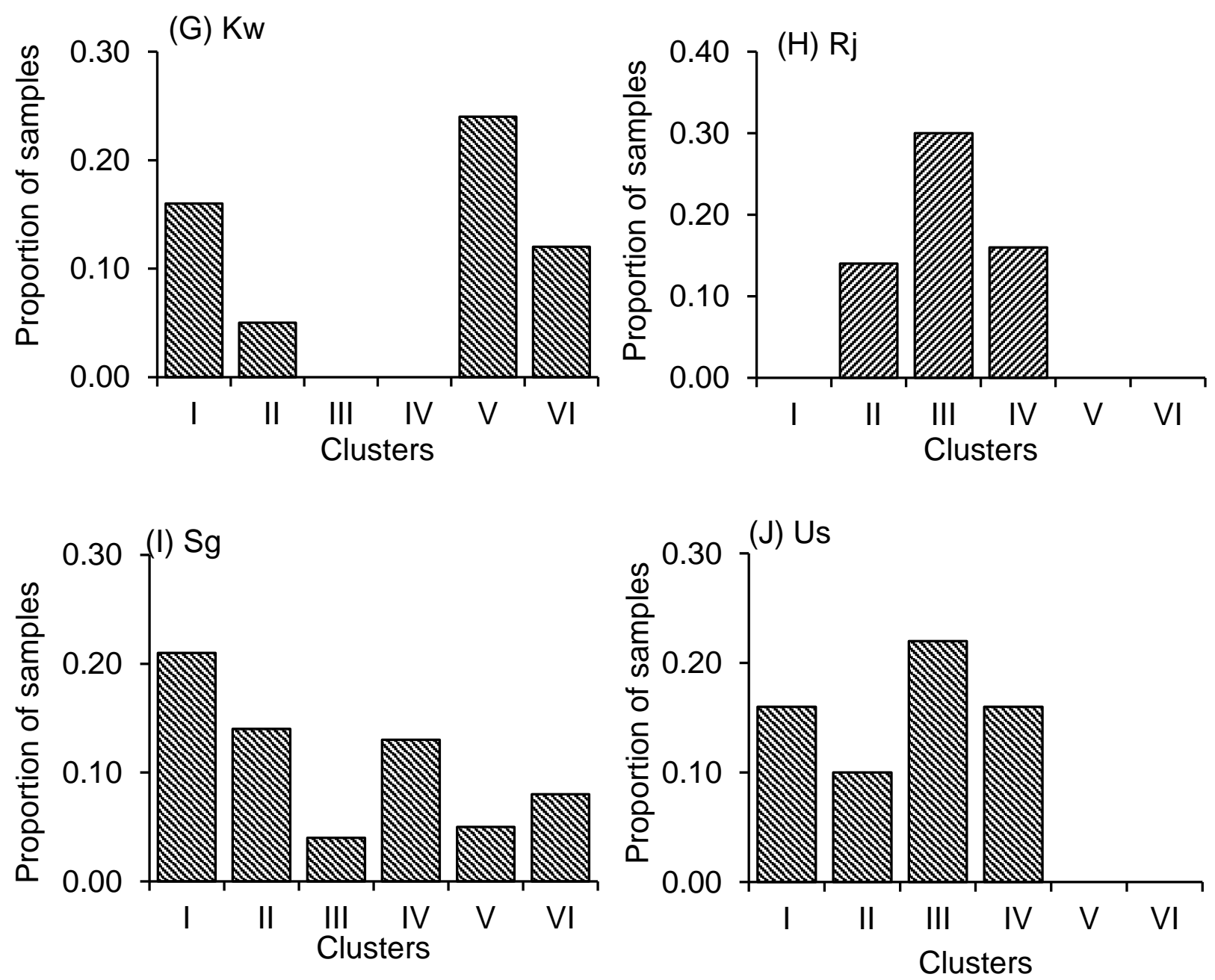

Figure 5. Histograms showing the proportion of samples in each reservoir in the six clusters. Abbreviations of reservoir names are as given in Table 1.
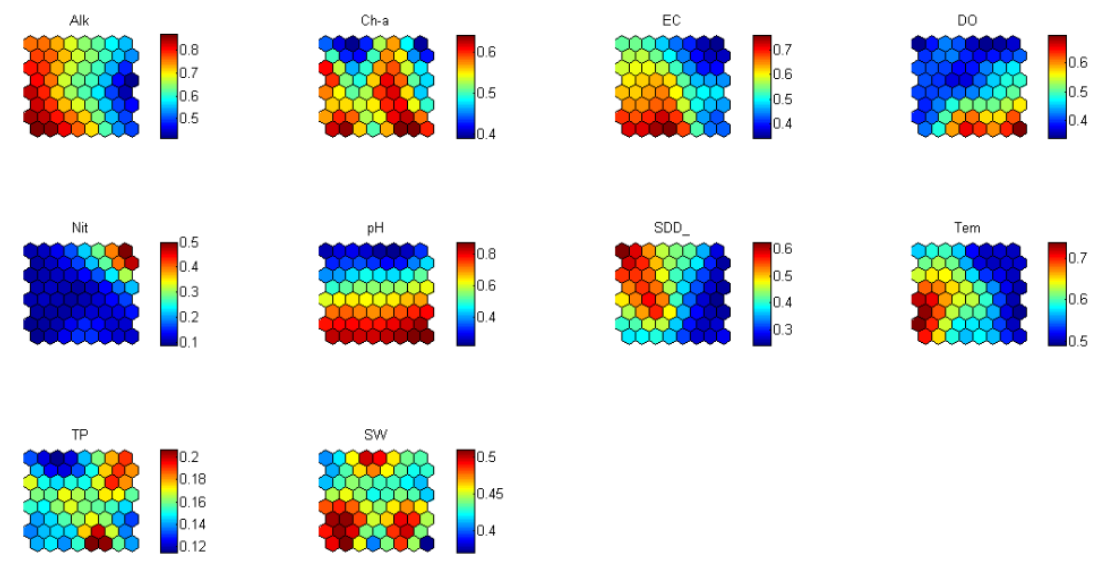

Figure 6. Visualization of the component plan of each water quality parameter in the SOM. The colour codes ranging from the low value (blue) to high value (red) indicate the relative importance of each parameter in the six clusters shown in Figure 4(A). 


\section{S. Nadarajah et al.}

Table 4 Dominant water quality parameters in the reservoirs of different categories of hydraulic retention time (HRT) and Relative Reservoir Water level fluctuations (RRWL). Most dominant water quality parameters are indicated in bold phase. Abbreviations of water quality parameters are as given in Table 2.

\begin{tabular}{|c|c|c|c|}
\hline Reservoir & $\begin{array}{l}\text { HRT } \\
\text { category }\end{array}$ & $\begin{array}{l}\text { RRWL } \\
\text { category }\end{array}$ & Dominant water quality parameters \\
\hline Angamuwa & $<0.5 \mathrm{yrs}$ & $100-200$ & Alk, SW, Temp, pH, SDD \\
\hline Balaluwewa & $<0.5 \mathrm{yrs}$ & $100-200$ & $\mathbf{p H}, \mathbf{T P}, \mathrm{DO}, \mathrm{Chl}-\mathrm{a}, \mathrm{SDD}, \mathrm{Alk}, \mathrm{SW}, \mathrm{Temp}$ \\
\hline Dewahuwa & $>1.5 \mathrm{yrs}$ & $>200$ & SDD, Alk, pH, DO, Chl-a, $\mathrm{NO}_{3}^{-}$, SW, Temp \\
\hline Ibbankatuwa & $<0.5 \mathrm{yrs} *$ & $>200$ & $\mathbf{N O}_{3}^{-}, \mathrm{SW}$, Temp, Alk, pH, DO, Chl-a \\
\hline Kalawewa & $<0.5 \mathrm{yrs}$ & $100-200$ & $\mathbf{p H}, \mathbf{T P}, \mathrm{DO}, \mathrm{Chl}-\mathrm{a}, \mathrm{SDD}, \mathrm{Alk}, \mathrm{NO}_{3}{ }^{-}, \mathrm{SDD}$ \\
\hline Kandalama & $<0.5 \mathrm{yrs}$ & $<100$ & $\begin{array}{l}\text { pH, TP, DO, Chl-a, SDD, Alk, } \mathrm{NO}_{3}^{-}, \mathrm{SW} \text {, } \\
\text { Temp }\end{array}$ \\
\hline Katiyawa & $<0.5 \mathrm{yrs}$ & $100-200$ & Alk, SW, Temp, pH, SDD, $\mathrm{NO}_{3}{ }^{-}, \mathrm{DO}, \mathrm{Chl}-\mathrm{a}$ \\
\hline Rajanganaya & $0.5-1.0 \mathrm{yrs}$ & $<100$ & SW, Alk, Temp, pH, SDD \\
\hline Siyambalangamuwa & $0.5-1.0 \mathrm{yrs}$ & $>200$ & SDD, Alk, SW, Temp, $\mathrm{pH}, \mathrm{NO}_{3}{ }^{-}$, DO, Chl-a \\
\hline Usgala & $1.0-1.5 \mathrm{yrs}$ & $100-200$ & SW, Temp, Alk, SDD, pH \\
\hline Siyambalangamuwa & & & \\
\hline
\end{tabular}

Although there was no clear pattern of water quality parameters in relation to HRT and RRWL, a high $\mathrm{NO}_{3}^{-}$content was reported in Ibbankatuwa reservoir having the lowest HRT and the highest RRLF, whereas higher alkalinity was recorded in Angamuwa reservoir where intermediate RRWL was registered (Figure 3; Table 4). These findings are substantiated by the interrelationships of some water quality parameters with HRT and RRWL (Figure 7).

\section{DISCUSSION}

In many applications of assessment and management of water quality in aquatic ecosystems, univariate statistical approaches are often employed but it is evident that there is no general model that can be appropriate for all situations (Telebbeydokhti et al. 2017). Approaches pertaining to water quality indices (WQI) in which the aspects of multipleattributes of water quality can be resolved into a single score sometimes does not provide sufficient information for decision makers (Abbasi and Abbasi 2012). Many WQIs are potentially useful in the planning of water resource protection, improvement, and utilization, whereas some WQIs have been specifically developed to aid in environmental planning and decision making. Several authors have shown that multivariate statistical approaches are more appropriate to understand the underpinning patterns of water quality parameters, especially due to their interdependence (e.g., Sheela et al., 2012; Avakul and Jutagate 2012).

The multivariate statistical approach employed in the present study has shown considerable variations of water quality among irrigation reservoirs studied, which are possibly associated with hydrological regimes. These multivariate approaches have been proven to be more suitable for the analysis of complex data and understand the underlying patterns in a simple manner (Lek and Guegan 2000; Li et al. 2009; Aguilera et al. 2001; Mahagamage et al. 2014; Mahagamage and Manage 2014). The Self-Organizing Map (SOM) approach adopted in the present analysis belongs to the category of competitive learning networks. The SOM, which is one of the artificial neural network models, is based on unsupervised learning without human intervention and little needs to be known about the characteristics of the input data. 
(a)
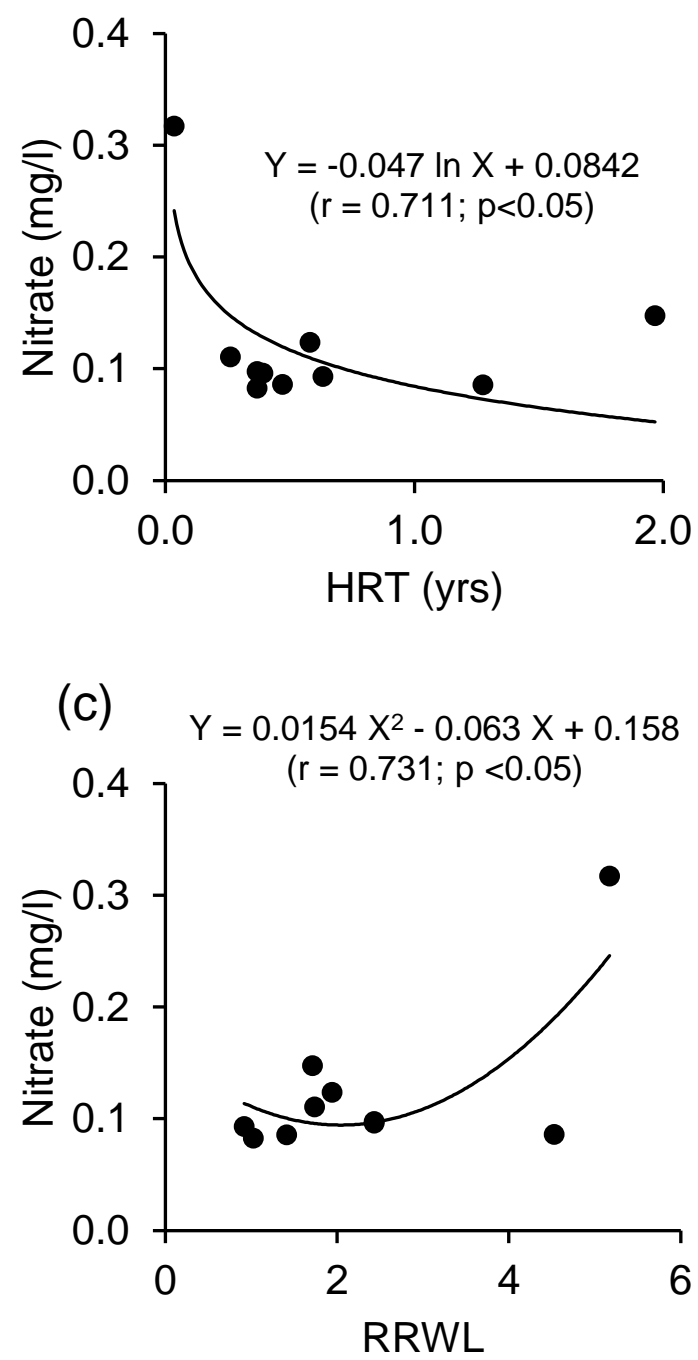

(b)

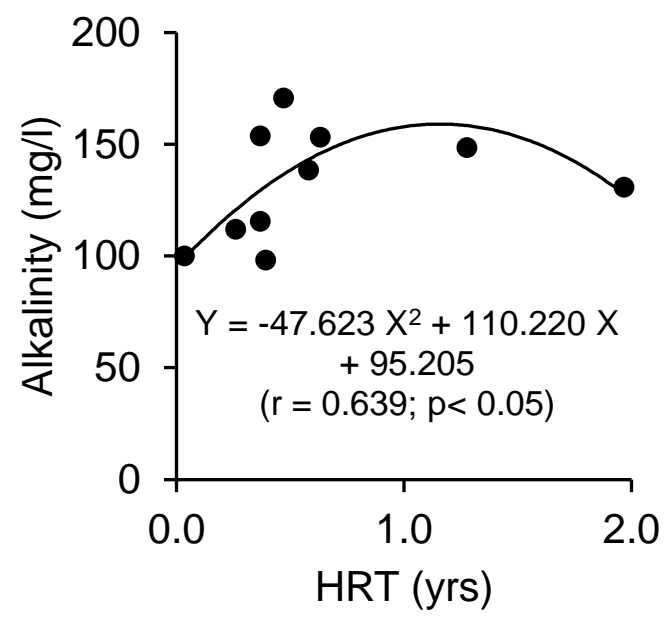

(d)

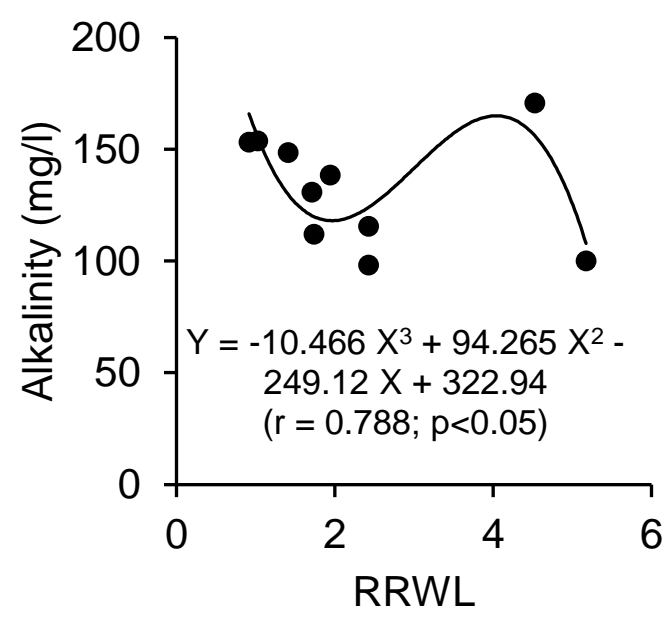

Figure 7. Relationships of some water quality parameters with HRT and RRWL in the 10 reservoirs studied.

In environmental assessment, it is imperative that methodologies which summarize complex environmental data into a simple visual format be employed especially for assisting decision makers. The present study indicates that the SOM approach is appropriate for the purpose because it provides an insight into how anthropogenic factors (in the present case HRT and RRWL) impact on the water quality of irrigation reservoirs. The present study was, however based on a few water quality parameters, which were important for planning fisheries management strategies in a parallel study. Nevertheless, this analysis has shown that HRT and RRWL influenced nutrient-related water quality parameters such as nitrate and alkalinity.
Furthermore, from the present analysis, it was evident that total phosphorous was not significantly influenced by either HRT or RRWL. Yatigammana \& Cumming (2016) also mentioned that Sri Lankan reservoirs could be categorized as phosphatelimited systems.

The practical utility of the present analysis is that the desired levels of water quality, which are in accordance with the water quality management criteria, can be achieved through control of HRT and RRWL. In the developing countries, reservoir management is generally aimed at increasing food fish production and as such, eutrophy is favoured (Welcomme and Bartley 1998). On the other hand, reservoir trophy may lead to the proliferation of 


\section{S. Nadarajah et al.}

toxigenic algae such as Micocystis (Jayatissa et al. 2006; Sethunga and Manage 2010; Manage et al 2010; Manage and Premathilaka 2011; Hettiarchchi and Manage 2014). Furthermore, the presence of toxigenic algae in some Sri Lankan reservoirs of drinking water supply due to eutrophic conditions has also been reported (Sethunge and Manage 2010). As such, strategies for the management of reservoir water quality should be viewed as a tradeoff between the trophic levels favouring biological production and preventing eutrophication which may bring about the proliferation of toxigenic algae. As HRT and RRWL can essentially be controlled through management of hydrological regimes in irrigation reservoirs, close dialogue between irrigation authorities and other users of reservoir water resources might be useful to ensure desired water quality.

\section{ACKNOWLEDGEMENTS}

University Grants Commission of Sri Lanka, through the Knowledge Enhancement and Institutional Development Fund, has provided financial assistance to carry out this research.

\section{REFERENCES}

Abbasi, T. and S.A. Abbasi 2012. Water Quality Indices. Elsevier, Amsterdam. https://doi.org/10.1016/B978-0-444-543042.01001-0

Aguilera, P.A., A.G. Frenich, J.A. Torres, H. Castro, J.L. Martinez Vidal and M. Canton 2001. Application of the Kohonen neural network in coastal water management: methodological development for the assessment and prediction of water quality. Water Research 35(17): 40534062. doi:10.1016/S0043-1354(01)00151-8

Amarasinghe, U.S. and S.S. De Silva 2015. Fishes and fisheries of Asian inland lacustrine waters. In: Freshwater Fisheries Ecology (ed. J.F. Craig). pp. 384-403. John Wiley \& Sons Ltd, Chichester, UK. doi: 10.1002/9781118394380.ch31

APHA, 2012. Standard Methods for the Examination of Water and Wastewater, $22^{\text {nd }}$ edn. American Public Health Association, Washington DC. 1496 p.

Avakul, P. and T. Jutagate 2012. Spatio-temporal variations in water quality of the Chao Phraya
River, Thailand, between 1991 and 2008. Journal of Water Resource and Protection 4: 725-732. http://dx.doi.org/10.4236/jwarp.2012.49082

De Silva, S.S. 1985. Observations on the abundance of the exotic cichlid Sarotherodon mossambicus (Peters) in relation to fluctuations in the waterlevel in a man-made lake in Sri Lanka. Aquaculture and Fisheries Management 16: 265272.

Dillon, P. J. 1975. The phosphorus budget of Cameron Lake, Ontario: The importance of flushing rate to the degree of eutrophy of lakes. Limnology and Oceanography 20: 28-39.

Fernando, C.H. 1993. Impact of Sri Lankan reservoirs, their fisheries, management and conservation. pp. 351-374. In: W. Erdelen, C. Preu, N. Ishwaran and C.M. Madduma Bandara (eds.) Ecology and Landscape Management in Sri Lanka. Proceedings of the International and Interdisciplinary Symposium, 12-16 March 1990, Colombo, Sri Lanka. Margraf Scientific Books, Weikersheim.

Hettiarachchi, I.U. and P.M. Manage 2014. Cyanobacterial cell density \& intracellular Microcystin-LR levels in drinking/ irrigation reservoirs in Anuradhapura, Sri Lanka, Journal of Environment and Natural Resources, Thailand. pp. 210-214.

Jayasinghe, J.M.P.K. and U.S. Amarasinghe 2018. Inland aquatic resources. In: Natural Resources of Sri Lanka: Conditions, Trends and Prospects. National Science Foundation of Sri Lanka, Colombo. (in press)

Jayatissa, L.P., E.I.L. Silva, J. McElhiney and L.A. Lawton 2006. Occurrence of toxigenic cyanobacterial blooms in fresh waters of Sri Lanka. Systematic and Applied Microbiology 29: 156-164. https://doi.org/10.1016/j.syapm.2005.07.007

Kawara, O., E. Yura and T. Matsumoto 1998. A study on the role of hydraulic retention time in eutrophication of the Asahi River Dam reservoir. Water Science and Technology 37(2): 245-252. https://doi.org/10.1016/S0273-1223(98)00030-4

Kennedy, R.H. 2005. Toward integration in reservoir management. Lake and Reservoir Management 21(2): 128-138.

DOI: $10.1080 / 07438140509354422$ 
Kohonen, T. 1982. Self-Organized Formation of Topologically Correct Feature Maps. Biological Cybernetics 43(1): 59-69.

Kohonen, T. 2001. Self-organizing maps. $3^{\text {rd }}$ edition. Springer, Berlin. 501 p.

Kolding, J. and P.A.M. van Zwieten 2006. Improving productivity in tropical lakes and reservoirs. CGIAR Challenge Program on Water and Food. Aquatic Ecosystems and Fisheries Review, Series 1. World Fish Center, Cairo, Egypt, pp. 139.

Kolding, and P.A.M. van Zwieten 2012. Relative lake level fluctuations and their influence on productivity and resilience in tropical lakes and reservoirs. Fisheries Research 115-116: 99-109. DOI: 10.1016/j.fishres.2011.11.008

Lek, S. and J.F. Guegan 2000. Artificial Neural Networks: Application to Ecology and Evolution. Springer Verlag, Berlin.

Lek, S., M. Scardi, P.F.M. Verdonschot, J-P. Desky and Y-S. Park (eds.) 2005. Modelling Community Structure in Freshwater Ecosystems. Springer-Verlag, Berlin. 518 p.

Li, Y., L. Xu and S. Li 2009. Water quality analysis of the Songhua River Basin using multivariate techniques. Journal of Water Resource and Protection 2(8): 110-121. doi:10.4236/jwarp.2009.12015

Mahagamage, M.G.Y.L., S.D.M. Chinthaka and P.M. Manage 2014. Multivariate analysis of physico-chemical and microbial parameters of surface water in Kelani river basin. International Journal in Multidisciplinary Studies (IJMS) 1: 55-61.

Mahagamage, M.G.Y.L. and P.M. Manage 2014. Water quality index (CCME-WQI) based assessment study of water quality in Kelani river basin, Sri Lanka. International Journal of Environment and natural resources 1: 199-204.

Manage, P.M., C. Edwards and L. Lawton 2010. Bacterial degradation of microcystin. Interdisciplinary Studies on Environmental Chemistry-Biological Responses to Contaminants. TERRAPUB: Tokyo: 97-104.

Manage, P.M. and S.N. Premetilake 2011. Occurrence of heterotrophic bacteria causing lysis of M. aeruginosa in Beira Lake, Sri Lanka. Vidyodaya Journal of Science 16: 31-56.
Rast, W. and M. Holland 1988. Eutrophication of lakes and reservoirs: A framework for making management decisions. Ambio 17(1): 2-12.

Sethunge, S. and P.M. Manage 2010. Nuisance algae in water supply projects in Sri Lanka. Proceedings of the International Conference on Sustainable Built Environment (ICSBE-2010), Kandy, 13-14 December 2010. pp. 62-70.

Sheela, A.M., J. Letha, S. Joseph, M. Chacko and J. Thomas 2012. Water quality assessment of a tropical coastal lake system using multivariate cluster, principal component and factor analysis. Lakes and Reservoirs: Science, Policy and Management for Sustainable Use 17(2): 143159.

Suryanarayana, I., A. Braibanti, R.S. Rao, V.A. Ramam, D. Sudarsan, G.N. Rao 2008. Neural networks in fisheries research. Fisheries Research 92: 115-139. http://dx. doi.org/10.1016/j.fishres.2008.01.012.

Telebbeydokhti, N., S. Porshahabi, D. Rakhshandehroo, M.R. Nikoo and M. Amiri 2017. Review of reservoir water quality monitoring and modeling. pp. 134-142. In: Proceedings of the 4th International Conference on Long-Term Behaviour and Environmentally Friendly Rehabilitation Technologies of Dams (LTBD 2017), October 2017, IRIB International Conference Centre in Tehran, Iran.

Tudesque, L., M. Gevrey, G. Grenouillet and S. Lek 2008. Long-term changes in water physicochemistry in the Adour-Garonne Hydrographic Network during the last three decades. Water Research 42(3): 732-742. doi:10.1016/j.watres.2007.08.001

Vesanto, J. 2000. Neural network tool for data mining: SOM toolbox. Proceedings of symposium on tool environments and development methods for intelligent systems (TOOLMET2000) pp.194-196. (Oulun yliopistopiano), Oulu, 2000.

Wagner, T. and Erickson, L.E. 2017. Sustainable management of eutrophic lakes and reservoirs. Journal of Environmental Protection 8: 436-463. https://doi.org/10.4236/jep.2017.84032

Welcomme R. L. \& Bartley D. M. (1998) Current approaches to the enhancement of fisheries. Fisheries Management and Ecology 5: 351-382. https://doi.org/10.1046/j.1365-

2400.1998.550351.x 
Wetzel R. G. 2001. Limnology: Lake and River Ecosystems. Third Edition. Academic Press, San Diego, Calfornia. 1006 p.

https://doi.org/10.1016/B978-0-08-0574394.50001-0

Yatigammana S.K. and B.F. Cumming 2016. Physical and chemical characteristics of ancient and recent reservoirs of Sri Lanka. Fundamental and Applied Limnolology 188 (3): 249-263. DOI: $10.1127 / \mathrm{fal} / 2016 / 0920$

Yu, Y.P., R. Omar, R.D. Harrison, M.K. Sammathuria and A.R. Nik 2011. Pattern clustering of forest fires based on meteorological variables and its classification using hybrid data mining methods. Journal of Computational Biology and Bioinformatics Research 3(4): 4752. 